\title{
Kamu kurumları için sıfır atık kapsamında atık kâğıt envanter çalışması: Artvin Çoruh Üniversitesi örneği
}

\author{
Waste paper inventory study within the scope of zero waste for public institutions: an \\ example of Artvin Çoruh University
}

\author{
Kazım Onur DEMIRARSLAN ${ }^{* 1, a}$, Serden BAŞAK ${ }^{2, b}$ \\ ${ }^{1}$ Artvin Çoruh Üniversitesi, Mühendislik Fakültesi, Çevre Mühendisliği Bölümü, Artvin \\ ${ }^{2}$ Artvin Çoruh Üniversitesi, Sağlık Bilimleri Fakültesi, İs Sağllğ l ve Güvenliği Bölümü, Artvin
}

- Geliş tarihi / Received: 09.02.2021

• Düzeltilerek geliş tarihi / Received in revised form: 13.08 .2021

- Kabul tarihi / Accepted: 23.08.2021

Öz

Kâğıt günümüzden yaklaşık 2000 yıl önce Çin Uygarlığı tarafından bulunmuş ve dünyaya yayılmıştır. Günümüzde ise kâğıdın yerine elektronik ortamlar kullanılmaya başlansa da dergi, gazete, önemli belge ve evraklar, kitaplar için kâğıt kullanımı sürmektedir. Bunun yanı sıra çeşitli paket ve ambalajlar için kâğıt kullanımı oldukça fazladır. Kâğıdın hammaddesini ise önemli miktarda ağaçlar oluşturmaktadır. Ayrıca üretim için oldukça fazla enerjiye ve suya gereksinim vardır. Bu nedenle günümüzde kâğıt hammaddesi olarak kullanılmış kâğıtlara yönelme artış göstermektedir. Sonuç olarak atık kâğıtların toplanması, taşınımı, geri dönüşümü başlı başına atık yönetim konusunu oluşturmuştur. Yapılan bu çalışmada ise kamu kurumlarından biri olan üniversitelerde kâğıt atık miktarları incelenmiştir. Çalışma alanı olarak Artvin Çoruh Üniversitesine bağlı Seyitler ve Şehir Yerleşkelerinden toplanan atık kâğıtlar bir sene boyunca incelenmiştir. Çalışma sonucunda bir yılda toplam $2179 \mathrm{~kg}$ kâğıt atık toplandığı belirlenmiştir. Kişi başına düşen aylık ortalama 0.045 $\mathrm{kg}$, yıllık ortalama ise $0.49 \mathrm{~kg}$ olarak bulunmuştur. Kâğıtların geçici depolama alanında toplanarak belirli aralıklarda hurda kâğıt toplayıcılarına verildiği tespit edilmiştir. Yapılan bu çalışmanın sıfır atığı hedefleyen kamu kurumlarında yapılacak atık kâğıt envanter çalışmaları için öncü bir çalışma olması hedeflenmiştir.

Anahtar kelimeler: Atık kâğıt, Envanter çalışması, Kamu kurumu, Sıfır atık

\begin{abstract}
The paper was discovered and spread to the world by the Chinese Civilization about 2000 years ago. Although electronic media is used instead of paper, the use of paper continues to be used for magazines, journals, essential documents, records, and books. Besides, the use of paper for various packages is quite high. The raw material of the paper consists mainly of wood. Hence, the use of waste paper as the raw material in the manufacture of paper is growing nowadays. As a consequence, the storage, transportation, and recycling of waste paper have become an issue of waste management. The amount of paper waste in universities, one of the public institutions, was investigated in this study. Waste papers collected from the Seyitler and City Campuses of Artvin Coruh University was tracked for one year. It was calculated from the study that a total of $2,179 \mathrm{~kg}$ of paper waste was obtained in one year. It was found that the monthly average per person was $0.045 \mathrm{~kg}$ and the annual average was $0.49 \mathrm{~kg}$. It was observed that the papers were collected in a temporary storage area and given to scrap paper collectors at certain periods. This study is aimed to be a pioneering study of waste paper inventory studies to be carried out in public institutions aiming at zero waste.
\end{abstract}

Keywords: Waste paper, Inventory study, Public institute, Zero waste

\footnotetext{
${ }^{*}$ a Kazım Onur DEMIRARSLAN; onurdemirarslan@artvin.edu.tr, Tel: (0466) 21510 00, orcid.org/0000-0002-1023-7584

${ }^{\mathrm{b}}$ orcid.org/0000-0002-5403-1609
} 


\section{Giriş}

Geçmiş ile gelecek arasında güçlü bir ilişki kuran kâğıt insanoğlunun geçmişten gelen anı, olay, destan gibi bilgi ve birikimlerini geleceğe aktarımını sağlayan bir belgedir (Güven vd., 2012). Kâğıt endüstrisinin geçmişi 2000 y1l öncesine dayanmakta olup günümüzde bu endüstri dünya çapında 5000 adet fabrikada y1lda 400 milyon ton kâğıt üreten bir sektör haline gelmiştir. Kâğıt yapım tekniklerine bakıldığında ise geçmişte uygulanan prensiplerle aynı olduğu görülmektedir (Toprak vd., 2019). Kâğıt endüstrisi enerji ve doğal kaynakları tüketen endüstrilerden bir tanesidir. Üretiminde lifler ve kimyasal maddeler dışında büyük miktarda su, buhar ve elektrik enerjisi kullanılmaktadır. Bunun yanında çevre üzerine de önemli etkileri olan bir sektördür. Özellikle üretim esnasında önemli miktarda kirletici çevreye verilmektedir (Cabalova vd., 2011; Gabrieli de Souza vd., 2017; Akay, 2019;). Günümüzde kâğıt hamurunun yaklaşık olarak \%90'1 ağaçtan elde edilmektedir. Kâğıt üretimi için dünyada her yıl 4 milyar ağaç kesilmekte ve bu oran kesilen ağaçların \%35'ini oluşturmaktadır. Sözü edilen rakamlar dünyanın toplam ekonomisinin \%1.2'sini temsil etmektedir (Bhattacharjee ve Islam, 2014; Ezeudu, 2019). Günümüzde kâğıdın geri dönüşümü atık yönetiminde uygulanan en köklü uygulamalardan bir tanesidir. Kâğıt geri dönüşümünden elde edilen kâğıt hamuru, özellikle kâğıt üretiminin önemli bir parçasıdır (Pivnenko vd., 2015). Kâğgdın geri dönüşümü yeni bir teknoloji olmayıp 1826'dan beri aynı prensipler uygulanmakta olup ancak 1960'lı yillara kadar bu konu üzerinde herhangi bir teknoloji geliştirilmemiştir (Cabalova, 2011). Kâğıt ve kartonların yapımında kullanılmış kâğıtların kullanımı ile çevrenin korunması ve enerji tasarrufu konularında önemli adımlar atılmaktadır (Lasheva vd., 2016). Atık kâğıtların türlerine bakıldığında büyük endüstri ve ticaret merkezlerinden gelen atık kâğıtlar, ofislerden kaynaklanan atık kâğıtlar ve evlerden kaynaklanan atık kâğıtlar olmak üzere sınıflandırılabilmektedir. $\mathrm{Bu}$ atık kâğıtların kalitesini ise renkli kâğgtlar, postit gibi yapışkanlı kâğıtlar, pul, çıkartma, bant içeren yapışkanlar, yiyecek-içecek ambalajı için kullanılan kâğıtlar bozabilmektedir (URL-1, 2020). Bir ton kâğgdın geri dönüşümü ile $\% 70$ hammadde, $\% 60$ kömür, $\% 43$ enerji ve $\% 70$ su tasarrufu sağlanmaktadır. Bunun yanında kişilere ek gelir ve istihdam olanağı da sağlamaktadır. Bazı kaynaklara göre bir ton geri dönüştürülmüş kâğıttan yaklaşık olarak 17 ağaç, 2.5 varil petrol, $4100 \mathrm{kWh}$ elektrik, $4 \mathrm{~m}^{3}$ depolama alanı ve 31780 It su tasarrufu sağlandığ
2011). Bir başka kaynağa göre ise 36 ton $\mathrm{CO}_{2}$ 'nin atmosfere salınmasının önlendiği gibi $276 \mathrm{~kg}$ kirletici gazların atmosfere karışması da önlenmiş olmaktadır. Bunun yanında 1750 lt kadar akaryakıt tasarrufu sağlandığı belirtilmektedir. Ayrıca da 85 $\mathrm{m}^{2}$, lik ormanlık alan kurtarılmaktadır (Sultan ve Gulnur, 2017). Ülkemizin üzerinde titizlikle durduğu ve kamu kurumlarının öncelik etmesi beklenen sifir atık projesine göre 02.04.2015 Resmi Gazete tarih ve 29314 sayılı Resmi Gazete'de yayımlanmış olan "Atık Yönetimi Yönetmeliği"nde kâğıt atıkları da önemli bir yer tutmaktadır (URL-3, 2015). Avrupa'da atıkların geri dönüşüm oran1 $\% 72$ olmasına rağmen Türkiye'de bu rakam son 10 yılda \%50'den fazla olamamıştır. Türkiye'de kâğıdın geri dönüşüm kapasitesi ve imkânları artsa da geri dönüşüm oranları aynı başarıyı yakalayamamıştır. Ülkemizin yaptığı kâğıt ithalatı önceki yıllarda 5060 bin ton/y1l iken 2014 yılında 183 bin ton/y1l, 2015 y1lında 250 bin ton/y1l ve 2016 y1lında 500 bin ton/yıl olmuştur. Kâğıt tüketimi ise yıllık 6-7 milyon ton civarında olduğundan maliyetler de hesaba katılırsa sürdürülebilir bir durum ne yazık ki görülmemektedir. $\mathrm{Bu}$ nedenle tek seçenek Avrupa'da olduğu gibi mevcut geri dönüşümü en az \%70 oranına yükseltmektir (Maden ve Arslankaya, 2017).

Atık kâğıtların envanterinin yapılması ayrıca önem taşımaktadır. Özellikle okul, üniversite gibi kamu kuruluşları sanayi tesislerinden sonra gelen ikinci en önemli kâğıt atık kaynağı olarak kabul edilmektedir (Dalkıllıç, 2012). Bu noktalarda meydana gelen atık kâğıt miktarlarının belirlenmesi sonucunda yönetiminin daha verimli bir şekilde planlaması yapılabilir. Yapılan bu çalışmada Artvin Çoruh Üniversitesi'ne (AÇÜ) bağlı Seyitler ve Şehir Yerleşkelerindeki birimlerde oluşan atık kâğıtların miktarları belirlenmiştir.

\section{Materyal ve metot}

Kamu binalarında meydana gelen atık kâğıt miktarlarının belirlenmesi amaçlanan bu çalışmada AÇÜ Seyitler ve Şehir Yerleşkeleri çalışma alanı olarak seçilmiştir. AÇÜ'nün bulunduğu Artvin 7367 km² yüzölçümüne sahiptir. İlde sanayi sektörü oldukça düşük seviyededir. İl merkezinin girişinde, Çoruh Nehri'nin kenarında, 70 dönüm arazi üzerine kurulan Şehir Yerleşkesinde Eğitim Fakültesi, Sağlık Bilimleri Fakültesi, Fen Edebiyat Fakültesi ve Sağlık Hizmetleri Meslek Yüksekokulu bulunmakta; ayrıca bir adet kongre ve kültür merkezi ile personelin ikamet ettiği 4 blokluk 40 haneli lojmanlar ve iki adet misafirhane 
yer almaktadır. Artvin il merkezine yaklaşık olarak $12 \mathrm{~km}$ uzaklıkta bulunan Seyitler Yerleşkesi ise 187 dönüm arazi üzerine kurulmuştur. Seyitler Yerleşkesinde Rektörlük, Rektörlüğe bağlı bazı birimler ile Orman Fakültesi, Mühendislik Fakültesi, Meslek Yüksek Okulu, Merkezi Araştırma Laboratuvarı, Sosyal Tesisler ile Sosyal Bilimler Enstitüsü ve Fen Bilimleri Enstitüsü yer almaktadır (Şekil 1) (Demirarslan, 2016;
Demirarslan ve Başak, 2017). AÇÜ Şehir ve Seyitler Yerleşkelerinde toplamda 63 adet atık kâğıt toplama kutusu bulunmaktadır. Bu kutuların birimlere göre sayıları ve bulundukları noktalar Tablo 1'de verilmektedir. Çalışma kapsamında bir sene boyunca ayda iki kez söz konusu kutulardan tartım yapılmıştır. Toplama kutularının ve atık kâğıt toplama noktasının örnek fotoğrafları Şekil 2'de verilmiştir.

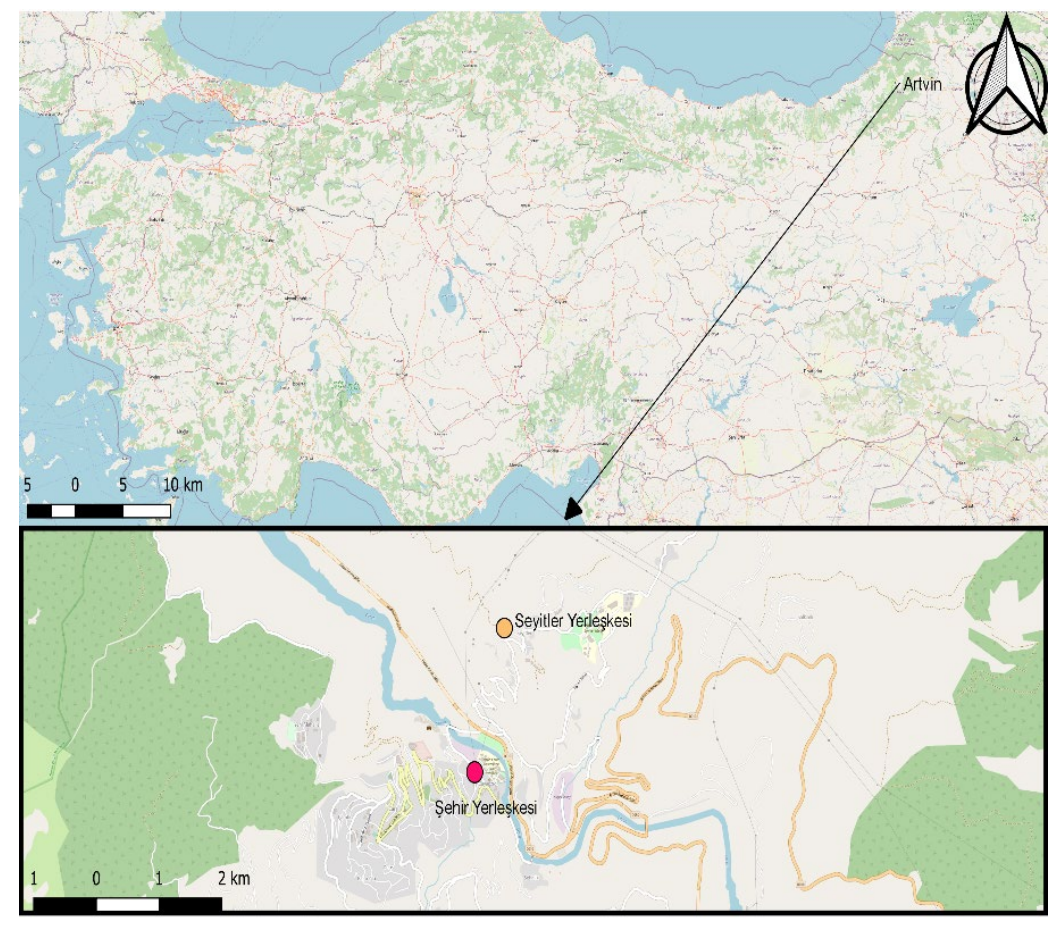

Şekil 1. Çalışma alanı
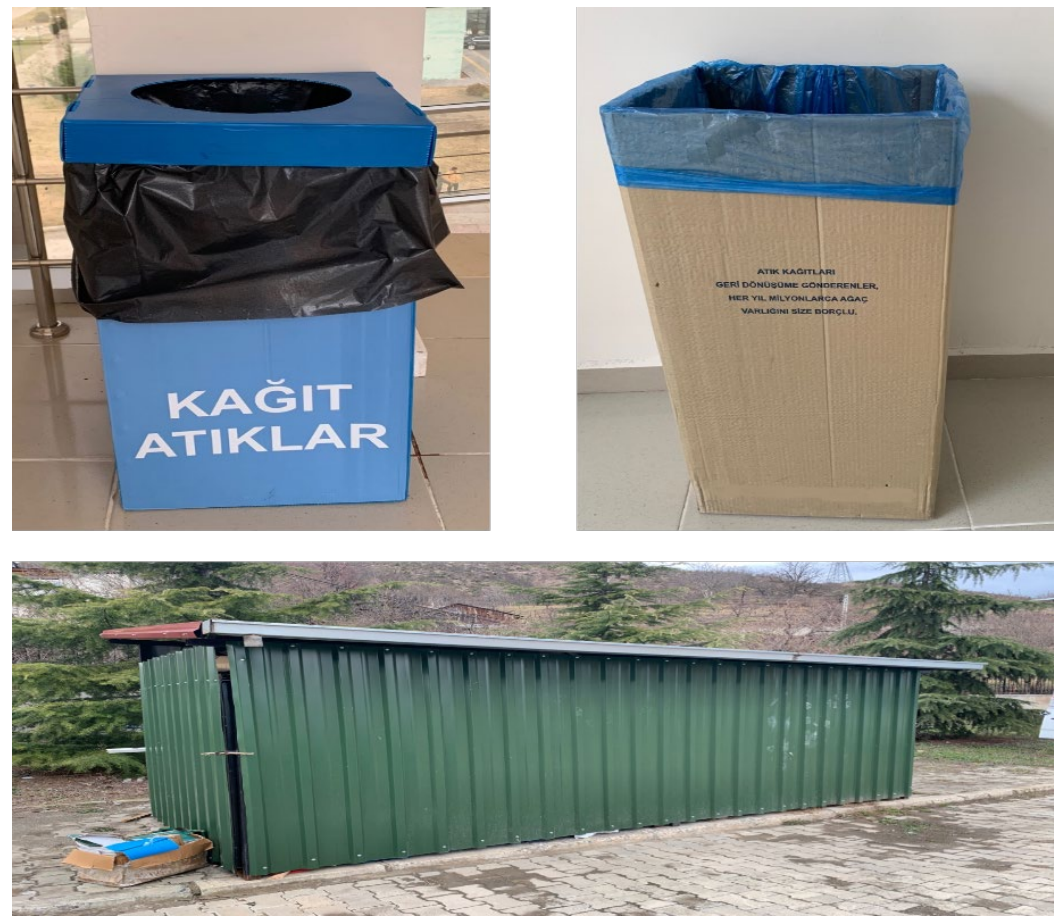

Şekil 2. Atık kâğıt toplama kutuları ve atık kâğıt toplama noktası 
Tablo 1. Atık kâğıt toplama kutularının yerleri ve sayıları

\begin{tabular}{lcc}
\hline Atık kâğıt toplama kutu yerleri & Kısaltması & Adet \\
\hline Şehir yerleşkesi & & \\
\hline Sağllk Bilimleri Fakültesi & SBF & 4 \\
Eğitim Fakültesi & EF & 3 \\
Fen Edebiyat Fakültesi & FEF & 3 \\
Sağllk Hizmetleri MYO & SHMYO & 3 \\
\hline Seyitler yerleşkesi & & \\
\hline Mühendislik Fakültesi & MF & 4 \\
Öğrenci İşleri & Öİ & 3 \\
Bilgi İşlem Daire Bşk. & BIDB & 2 \\
Fen Bilimleri Enstitüsü & FBE & 1 \\
BAP Koordinatörlüğü & BAP & 1 \\
Orman Fakültesi & OF & 17 \\
Yazı İşleri & Yİ & 1 \\
Personel Daire Bşk. & PDB & 1 \\
Strateji Geliştirme Daire Bşk. & SGDB & 3 \\
İdari ve Mali İşler Daire Bşk. & IMİDB & 3 \\
Basın ve Halkla İlişkiler & BHİ & 1 \\
Rektörlük & RKTLK & 5 \\
Artvin MYO & AMYO & 8 \\
\hline
\end{tabular}

\section{Bulgular}

Birimlere göre elde edilen ilkbahar-yaz mevsimlerinin atık kâğıt verileri Şekil 3'te verilmektedir. Şekil 3 incelendiğinde ilkbahar ve yaz aylarında en yüksek atık kâğıt oranının Orman Fakültesi'nde olduğu görülmektedir. İlkbahar aylarında en yüksek ikinci oranın İdari Mali İşler Daire Başkanlığında, yaz aylarında ise ikinci en yüksek değerin Şehir Yerleşkesindeki Eğitim Fakültesinde olduğu anlaşılmıştır. Diğer taraftan en az atık kâğıdın toplandığı yer ise Basın ve Halkla İlişkiler birimidir.

Şekil 4'te ise sonbahar ve kış aylarında birimlere göre toplanan atık kâğıtların miktarları ve yüzdeleri verilmektedir. Buna göre sonbahar ve kış aylarında da en fazla miktar Orman Fakültesine aittir. İkinci en yüksek miktar ise sonbahar aylarında
Rektörlüğünde bulunduğu idari kısımda, kış aylarında ise Fen Edebiyat Fakültesinde toplandığı tespit edilmiştir.

Tablo 2'de birimlere göre toplanan kâğıtların minimum, maksimum, ortalama değerleri ile bunlara bağlı standart sapmaları verilmektedir. Tablo 2'deki standart sapmalar incelendiğinde SBF, EF, FEF, SHMYO, BİDB, BHİ birimlerinde aylara göre toplanılan kâğıt miktarlarının oldukça değişkenlik gösterdiği anlaşılabilmektedir. Diğger birimlerde ise standart sapma ortalamadan küçük olduğu görülmekte bu durumunda aylık toplanan kâğıt miktarları arasında yakınlık olduğu söylenebilmektedir. Birimlerde çalışanlar ve öğrencilerin toplam sayısı 4420 kişidir. Aylara göre kişi başı atık kâğıt miktarları ise Şekil 5' te verilmektedir. 


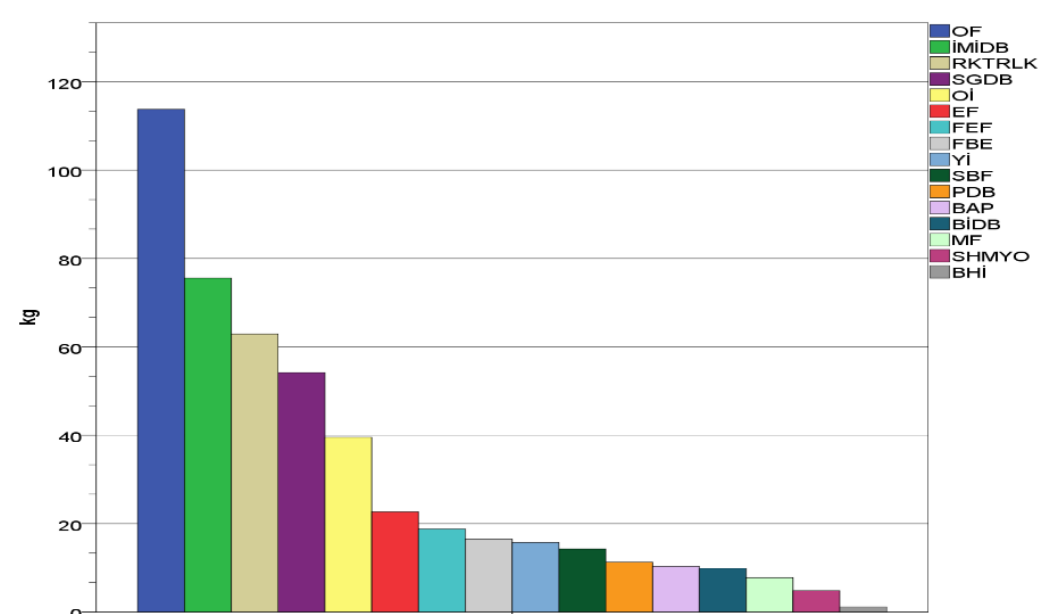

a. Ilkbahar Ağırlık Dağıımı

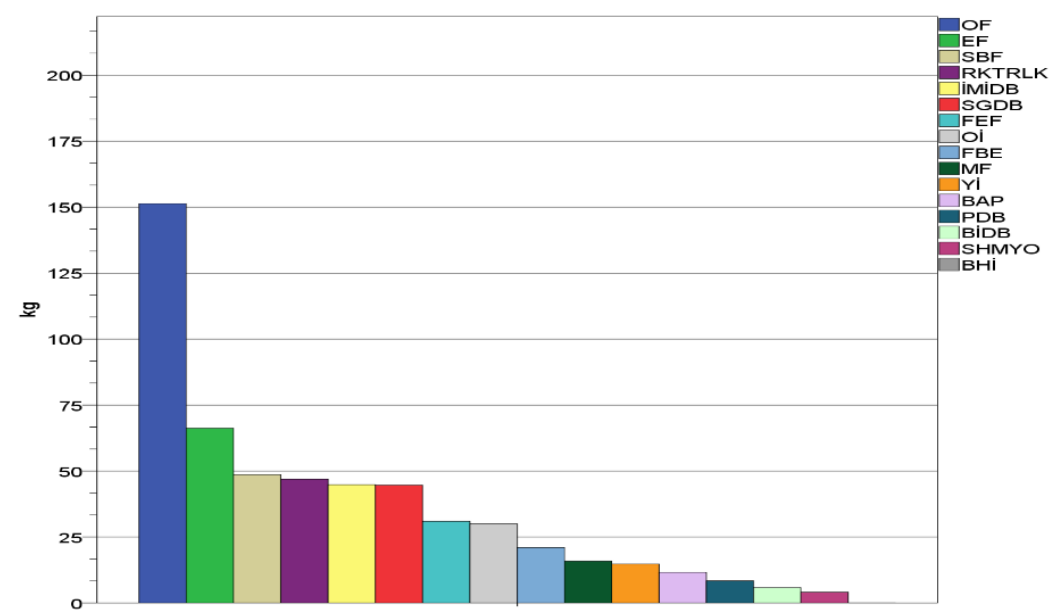

c. Yaz Ağırlık Dağılımı

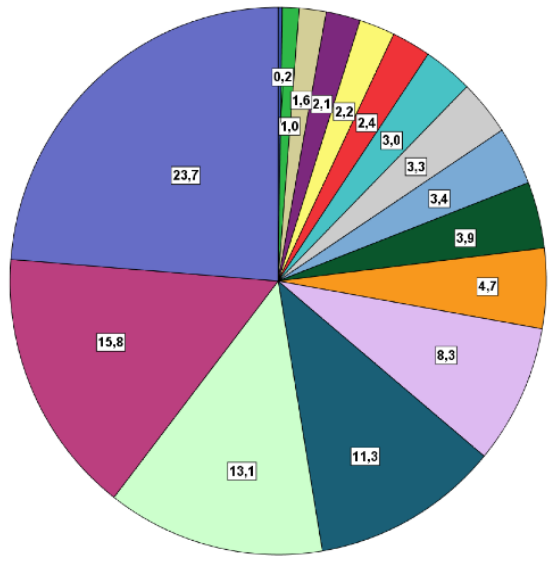

b. İlkbahar Yüzde Dağılımı

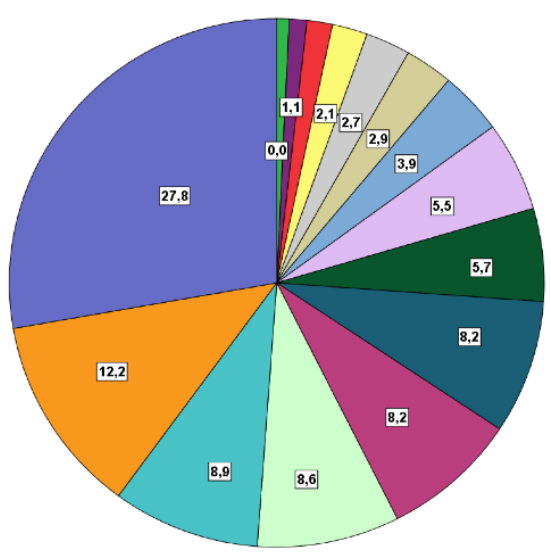

d. Yaz Yüzde Dağılımı

Şekil 3. İlkbahar-yaz mevsimi birimlere göre toplanan kâğıt miktarı

Şekil 5'teki grafik incelendiğinde kişi başına en fazla kâğıt atığın toplandığı ayın Ocak ayı olduğu görülebilmektedir. Bunun dışında Şubat, Haziran ve Aralık ayı ikinci sırada gelmektedir. Diğer aylarda ise miktarın azaldığı anlaşılmıştır. Kişi başına düşen aylık ortalama $0.045 \mathrm{~kg}$, yıllık ortalama ise $0.49 \mathrm{~kg}$ olarak bulunmuştur.

Birimlerde bulunan atık kâğıt toplama kutularında biriktirilen kâğıtlar düzenli olarak alınarak Seyitler Yerleşkesinde bulunan toplama noktasına (Şekil 2) ulaştırılmakta ve hava şartlarından etkilenmeden saklanmaktadır. Burada toplanan kâğıtlar ise belirli aralıklarla üniversite gözetiminde kâğıt toplayıcıları tarafından alınmaktadır.

Şubat 2020 tarihinde bir web sitesinden alınan hurda kâğıt fiyatları incelendiğinde özellikle karışık kâğıt atıkların kilosu $0.30 \mathrm{TL}$ olduğu belirlenmiş̦tir (URL-4, 2020). Hâlihazırda üniversite kâğıtları satmamasına rağmen teorik olarak 1 yılda toplanan toplam atık kâğıt miktarı $2179 \mathrm{~kg}$ olduğundan buna göre elde edilebilecek atık kâğıtların hurda dönüşüm fiyatı yaklaşı 654 TL hesaplanmıştır. Çevresel kazanımlara bakıldığında Tablo 3'teki veriler elde edilmektedir (URL-5, 2020). 


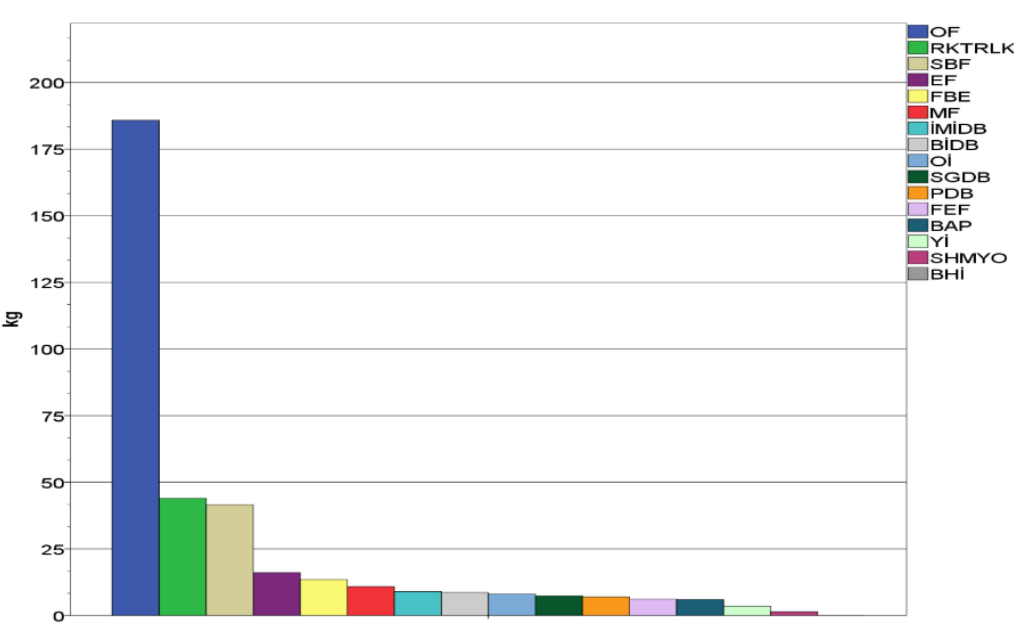

a. Sonbahar Ağırlık Dağılımı

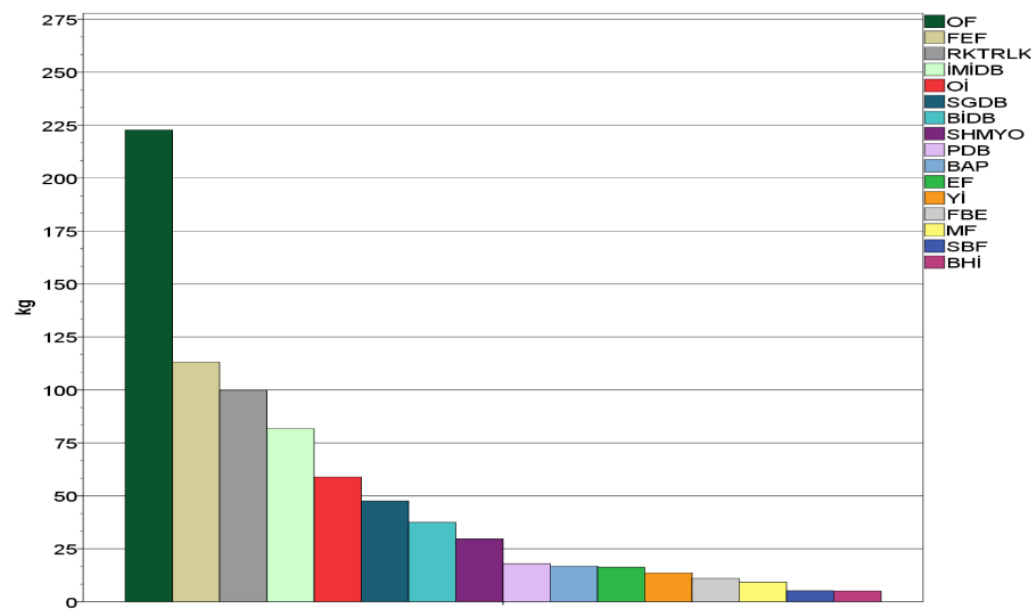

c. Kış Ağırlık Dağııımı

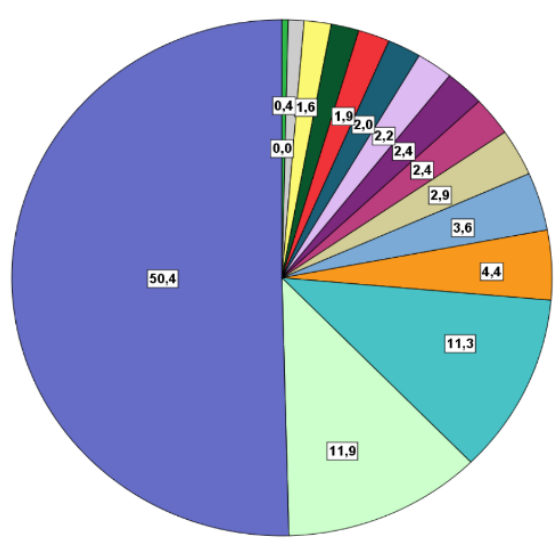

b. Sonbahar Yüzde Dağılımı

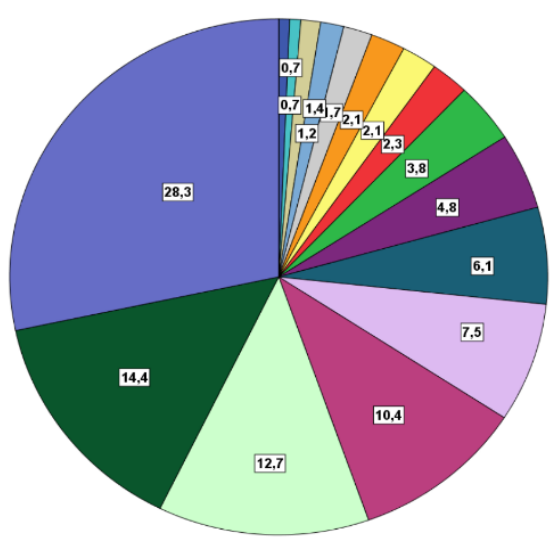

d. Kış Yüzde Dağılımı

Şekil 4. Sonbahar-kış mevsimi birimlere göre toplanan kâğıt miktarı

Tablo 2. Birimlere göre toplanan atık kâğıtların istatistiksel değerlendirmesi

\begin{tabular}{lcccc}
\hline Birimler & Min. (kg) & Maks.(kg) & Ort.(kg) & Std.sapma \\
\hline SBF & 0 & 26.13 & 8.43 & 9.72 \\
EF & 1.69 & 48.09 & 9.32 & 12.16 \\
FEF & 0.13 & 46.68 & 13.00 & 14.60 \\
SHMYO & 0 & 16.68 & 3.06 & 4.80 \\
MF & 0 & 7.58 & 3.36 & 2.67 \\
ÖI & 1.49 & 26.79 & 10.49 & 7.98 \\
BİDB & 0.95 & 20.49 & 4.75 & 5.54 \\
FBE & 0 & 13.32 & 4.76 & 4.19 \\
BAP & 0 & 7.52 & 3.43 & 2.42 \\
OF & 24.73 & 126.68 & 51.81 & 26.36 \\
Yİ & 0 & 9.87 & 3.65 & 2.99 \\
PDB & 0 & 7.56 & 3.42 & 2.63 \\
SGDB & 0 & 27.36 & 11.82 & 9.16 \\
IMIDB & 0 & 46.20 & 16.23 & 13.86 \\
BHI & 0 & 2.37 & 0.48 & 0.81 \\
RKTRLK & 2.78 & 38.62 & 19.50 & 10.37 \\
TOPLAM & $\mathbf{3 1 . 7 7}$ & $\mathbf{4 7 1 . 9 4}$ & $\mathbf{1 6 7 . 5 1}$ & \\
\hline
\end{tabular}




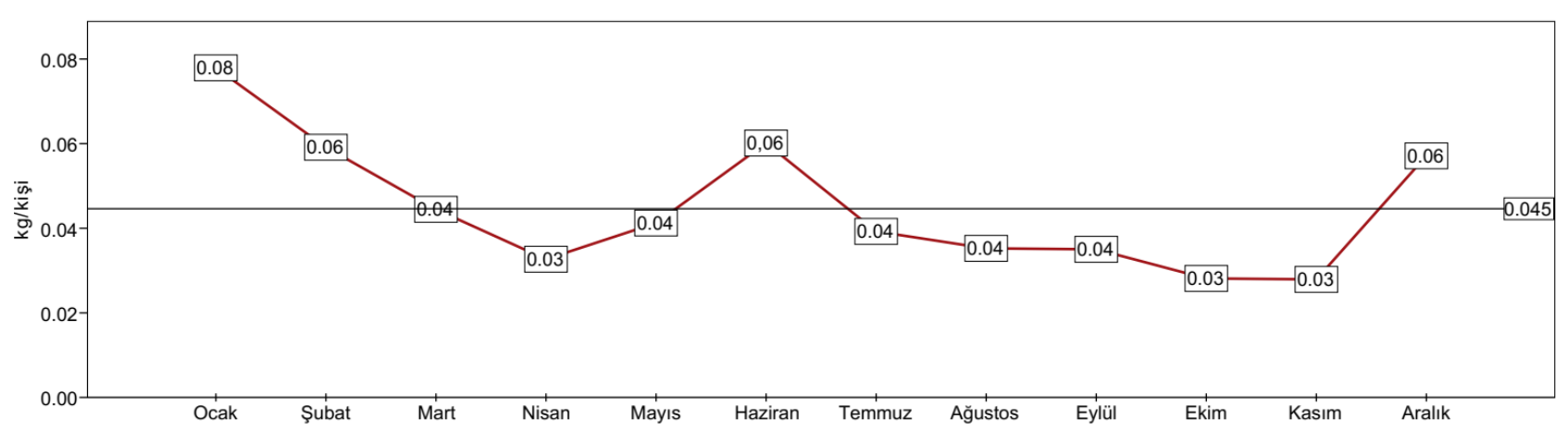

Şekil 5. Aylara göre kişi başına toplanan atık kâğıt miktarı

Tablo 3'te görüldügü üzere bir y1lda toplanan kâğıt atıklar sonucu ciddi oranda çevresel ve enerji tasarrufu elde edilmiştir. Özellikle enerji ve su kullanımında önemli tasarrufların sağlandığ görülebilmektedir. Ağaç kullanım tasarrufu incelendiğinde toplamda 57.5 adet ağacın kesilmekten kurtarıldığı görülmektedir (URL-5,
2020). Toplam enerji tasarrufu ise y1llik 73 adet evsel buzdolabının çalışmasına eşittir. Sera gazı emisyonları ise yılda 4 aracın yaydığı emisyon kadardır. Su kullanım tasarrufu da y1llık 37 adet sifonun kullanımına denk gelmektedir (URL-5, 2020).

Tablo 3. Toplanan kâğıt atıklar sonucu oluşan tasarruf detayları

\begin{tabular}{lc}
\hline Tasarruf kalemi & Tasarruf miktarı (br/yıl) \\
\hline Ağaç Kullanımı & $8.7 \mathrm{Ton}$ \\
Enerji Kullanımı & $17877 \mathrm{kwh}$ \\
Sera Gazları emisyonu & $19.5 \mathrm{ton} \mathrm{eq} \mathrm{CO}_{2}$ \\
$\mathrm{Su}$ Kullanımı & $194.570 \mathrm{~m}^{3}$ \\
$\mathrm{NO}_{\mathrm{x}}$ emisyonu & $2350 \mathrm{O}_{3} \mathrm{eq} / \mathrm{m}^{3}$ \\
$\mathrm{PM} \mathrm{emisyonu}_{\mathrm{SO}}$ emisyonu & $767 \mathrm{PM} 2.5 \mathrm{eq} / \mathrm{m}^{3}$ \\
$\mathrm{UOB}$ emisyonu & $8.93 \mathrm{~kg}$ \\
Kimyasal Oksijen İhtiyacı & $0.18 \mathrm{~kg}$ \\
Biyolojik Oksijen İhtiyacı & $20.77 \mathrm{~kg}$ \\
Ormansizlaşma & $9.88 \mathrm{~kg}$ \\
Civa Emisyonu & $3642 \mathrm{~m}$ \\
Dioksin Emisyonu & $87.2 \mathrm{mg}$ \\
\hline
\end{tabular}

\section{Tartışma ve sonuç}

Yapılan bu çalışmada AÇÜ Seyitler ve Şehir yerleşkelerinde toplamda 63 adet atık kâğıt toplama kutusunda toplanan atık kâğ itlar bir sene boyunca ayda iki kere tartılarak değerlendirilmiştir. Sonuçlar incelendiğinde en az kâğıdın Basın ve Halkla İlişkiler Biriminden kaynaklandığ1 görülmektedir. Bunun başlica sebebi ise çalışan sayısının az olmasından çok birimin işlemlerini sanal ortamda yürütmesinden kaynaklanmaktadır. Şehir Yerleşkesindeki öğrenci sayısı Seyitler Yerleşkesine göre daha çoktur. Bu bilgi dikkate alındığında dönem sonlarında Şehir Yerleşkesindeki birimlerde atık kâğıtlarda ciddi bir artış olduğu belirlenmiştir. Nedeni incelendiğinde ise öğrencilerin final ve bütünleme sonrasında yıllık ders notlarını atık kâğıt toplama kutularına atmaları olarak tespit edilmiştir.
İdari birimlerin fazla olduğu Seyitler Yerleşkesinde ise mali yılın kapanması ve süreli evrakların süresinin dolması sonucunda atık kâğıt miktarlarında ciddi artışlar görülmüş̧ür. Yapılan çalışma sonucunda atık kâğıtların toplanması ile önemli miktarda ekonomik ve çevresel kazançların olduğu belirlenmiştir. Ancak bu miktarlar yeterli olmayıp arttırılabilir niteliktedir. Atık kâğıtların geri kazanımı konusunda çalışan ve ögrencilerin daha çok bilinçlendirilmeleri, tek yüzü yazılmış kâğıtların arkalarını taslak çıktı almak veya ders çalışmak için kullanmaları, her iki yüzü yazılmış kâğıtların yapışkanlardan ve zımba tellerinden arındırılarak atık kâğıt toplama kutularına atılmaları geri dönüşümü kolaylaştıracak ve maliyeti düşürecek adımlardan olacaktır. İyi yönetilecek bir bilinçlendirme kampanyası sonrasında, bu çalışma sırasında toplanan kâğıttan 
çok daha fazlasının toplanması, ayrıca bunların satılarak hem katı atık bertaraf tesislerine daha az yük binmesini hem de kuruma ek bir gelir sağlanabilmesi öngörülmektedir. Bunun yanında başta kamu kurumlarının Elektronik Belge Yönetim Sistemine (EBYS) geçişlerinin tamamlanmas1 ve kurumlar aras1 entegrasyonun sağlanması hem zaman tasarrufu sağlayacak hem de atık kâğıt oluşumunu engelleyecek unsurların başında gelmektedir. Yapılan bu çalışmada Basın ve Halkla İlişkiler Bölümünün en az atık kâğıt üreten birim olması dijitalleşmenin önemini göstermektedir. Ayrıca öğrencilere ders notu olarak fotokopi dağıtmak yerine dünyaca kabul görmüş ve hangi cihazdan görüntülenirse görüntülensin format değişikliğine yol açmayan Taşınabilir Belge Biçimi (Portable Document Format, pdf) şeklinde dosyaların paylaşılması, öğrenciler üzerindeki maddi yükü ve dönem sonlarında oluşan atık kâğıt miktarlarını da azaltacaktır. Çoğu kamu kurumu doğalgaza geçmiş olduğundan atık kağıtların yakılması da bir çözüm değildir. Yakılan kağıtlar daha çok hava kirliliğine ve hem bacaların tikanması hem de ekonomik değeri olan bir ürünün yitirilmesine sebep olmaktadır. Önemli evraklar kağıt atığına gönderilmeden önce kağıt imha makinesi ile imha edilerek atılabilir.

"Sıfır Atık"; israfın önlenmesini, kaynakların daha verimli kullanılmasını, atık oluşum sebeplerinin gözden geçirilerek atık oluşumunun engellenmesi veya minimize edilmesi, atı̆̆ın oluşması durumunda ise kaynağında ayrı toplanması ve geri kazanımının sağlanmasını kapsayan atık yönetim felsefesi olarak tanımlanan bir hedeftir (URL-3, 2015). Tüm önlemlere ve dijitalleşmeye rağmen açı̆̆a çıkması muhtemel kağıt atıklarının toplanarak yeniden kağıt haline getirilmesinin (Özbakır Umut vd., 2015) yanı sıra, mobilya tasarımı (Şahin, 2018) veya inşaat ve konstrüksiyon malzemesi (Binici vd., 2013; Aydın İpekçi vd., 2017) olarak kullanılması gibi farklı yollarla değerlendirilmesi de mümkündür. $\mathrm{Bu}$ sayede farklı sektörlerde kullanılacak atık kâğıtlar, hem çevreyi kirletmeyecek hem de kullanılan sektörün çevreye karşı daha duyarlı olması sağlanacaktır. Özellikle kamu kurumlarının diğer kurumlara ve tüzel kişilere örnek olması için atık kâğıttan başlayarak diğer geri dönüştürülebilir ürünlerin toplanmasi hem ülke ekonomisine hem de çevre koşullarına olumlu katkıda bulunacaktır. İlgili kuruluşlar ve üniversiteler tarafindan atıkların farklı sektörlerde yeniden kullanılması için Ar-Ge çalışmaları da yürütülebilir.

\section{Kaynaklar}

Akay, Ö. (2019). Kâğıt ve kâğıt ürünleri üretimi ve gayri safi yurt içi hasılanın elektrik enerjisi tüketimine etkisi. Süleyman Demirel Üniversitesi Fen Bilimleri Enstitüsü Dergisi, 23(3), 1006-1012. https://doi.org/10.19113/sdufenbed.565505

Aydın İpekçi, C., Coşkun, N. ve Tıkansak Karadayı T. (2017). İnşaat sektöründe geri kazanılmış malzeme kullanımının sürdürülebilirlik açısından önemi, Türk Bilim Araştırma Vakfi, $10(2), 43-50$.

Bhattacharjee, D. and Islam, K. (2014). Development of a paper recycling process. Proceedings of the 15th Annual Paper Meet, (pp. 1-6). Dhaka, Bangladesh.

Binici, H., Küçükönder, A., Sevinç, A.H., Eken, M. ve Tüfenk, N. (2013). Atık kâğıt ve mukavvaların yalıtım malzemesi ve radyasyon tutucu materyal olarak üretiminde kullanılması. Çukurova Üniversitesi Mühendislik Mimarlı Fakültesi Dergisi, 28(1), 21-29.

Cabalova, I., Kačík, F., Geffert, A. and Kačíková, D. (2011). The effects of paper recycling and its environmental impact. the effects of paper recycling and its environmental impact, Chapters, in: Elzbieta Broniewicz (ed.), Environmental Management in Practice, IntechOpen. https://doi.org/10.5772/23110

Dalkılıç, Y. (2012). Atık kağıt geri dönüşümünde karşılaşılan sorunlar (Bahçelievler Belediyesi örneği). Yüksek Lisans Tezi, İstanbul Üniversitesi Fen Bilimleri Enstitüsü. İstanbul.

Demirarslan, K.O. (2016). Kentsel gelişmenin hava kalitesi üzerine etkileri ve Doğu Karadeniz Bölgesi. Karadeniz Araştırmaları Dergisi, 52, 27-55. http://dx.doi.org/10.12787/KARAM1120

Demirarslan K.O. and Başak S. (2017). Traffic-related $\mathrm{CO}_{2}$ dispersion and its effects: cases of Artvin Coruh University City Campus and Seyitler Campus. Arapgirlioglu, H., Atik A., Elliott R. L., Turgeon E. (Eds.), Researches on Science and Art in 21 st Century Turkey, (s. 814-822), Gece Publishing, 814-822.

Ezeudu, O.B., Agunwamba, J.C., Ezeasor, I.C. and Madu, C.N. (2019). Sustainable production and consumption of paper and paper products in Nigeria: A review. Resources, 8(53), 1-23. https:// doi.org/10.3390/resources 8010053

Gabrieli de Souza, A., Kano, F.S., Bonvent, J.J. and Rosa, D.D.S. (2017). Cellulose nanostructures obtained from waste paper industry: a comparison of acid and mechanical isolation methods. Materials Research, 20(2), 209-214. 
https://doi.org/10.1590/1980-5373-MR-20160863

Güven N., Kaplanoğlu L. ve Yangöz H. (2012). Kağıt yüzeyine uygulanan sanat eserlerinde kağıdın önemi. Akdeniz Sanat Dergisi, 5(9), 46-59.

Lasheva, V., Todorova, D., Kotlarova, S. and Kamburov, M. (2016). Deinking of waste offset printed paper by the use of enzymes. scientific proceedings. International Scientific Conference High Technologies. Business. Society 2016, Year XXIV, Volume I, P.P. 40-42

Maden, S. and Arslankaya, E. (2017). Regional waste paper recycling inventory study in Turkey and distribution of recycling quality classes. International Journal of Notural and Engineering Sciences, 1(3), 34-38.

Özbakır Umut M., Topuz Y. ve Nurtanis Velioglu M. (2015). Çöpten geri dönüşüme giden yolda sürdürülebilir tüketiciler, Celal Bayar Üniversitesi Sosyal Bilimler Dergisi, 13(2), 263288. https://doi.org/10.18026/cbusos.68623

Pivnenko, K., Eriksson, E. and Astrup, T.F. (2015). Waste paper for recycling: overview and 1dentification of potentially critical substances. Waste Management, 45, 134-142. https://doi.org/10.1016/j.wasman.2015.02.028

Sultan B and Gulnur M.E. (2017). Contribution to national economy of waste paper recycling (example of Turkey's hotels). International Journal of Environmental Sciences \& Natural, 2(1),
https://doi.org/10.19080/IJESNR.2017.02.55557 7

Şahin S. (2018). Mobilya tasarımında ekolojik malzeme açısından kağıt kullanımı, Mimarlık ve Yaşam Dergisi, 3(1), 53-61. https://doi.org/10.26835/my.367862

Toprak, D., Yılmaz, G., Yılmaz., T., Gülpınar, K., Çakmak, Y., Yücel, A. ve Uçar, D. (2019). Kağıt endüstrisi atıksularının biyolojik arıtılabilirliği, biyogaz üretimi ve çoklu reaktör sistemleri ile süreç optimizasyonu. Harran Üniversitesi Mühendislik Dergisi, 4 (3), 29-37.

URL-1, The European Commission's Science and Knowledge Service, The JRC in Seville (Spain), (2020, 21 Ocak) https://ec.europa.eu/jrc/en/about/jrcsite/seville? $\mathrm{id}=4139$.

URL-2, Ministry of Environment and Forests Notification, 12th May 2011 on e-waste (Management and Handling) Rules, 2011, (2020, 21 Ocak), moef.nic.in/downloads/ rules-andregulations/ 1035e_eng.pdf.

URL-3, Atık Yönetimi Yönetmeliği, Resmi Gazete Tarihi: 02.04.2015 Resmi Gazete Sayıs1: 29314, (2020, $13 \quad$ Şubat) https://cygm.csb.gov.tr/yonetmelikler-i-440.

URL-4, http://www.agdhurda.com/hurda-fiyat-listesi. (2020, 13 Şubat).

URL-5, https://c.environmentalpaper.org/. (2020, 13 Şubat). 